\title{
DETERMINATION OF CHROMATOGRAPHIC ASSAY AND VALIDATION OF OFLOXACIN IN BULK AND PHARMACEUTICAL DOSAGE FORM
}

\author{
Sumithra M*, Attah Samuel Attah, Gnana Sowndariya A \\ Department of Pharmaceutical Chemistry and Analysis, School of Pharmaceutical Sciences, Vels Institute of Science, Technology and \\ Advanced Studies, Chennai, Tamil Nadu, India. Email: Sumithrapharmanalysis@gmail.com
}

Received: 10 October 2018, Revised and Accepted: 11 December 2018

\section{ABSTRACT}

Objective: The objective of the study is simple, sensitive; eco-friendly reverse phase chromatographic method has been developed and validated for the quantitative determination of ofloxacin in bulk and marketed formulation.

Method: The developed method was done using Hypersil silica C18 (250 $\mathrm{mm} \times 4.6 \mathrm{~mm}, 5 \mu$ particle size) as column and the mobile phase is containing water and methanol in the ratio of (10:90) vol/vol. The mobile phase pass at $1 \mathrm{ml} / \mathrm{min}$ flow rate and the eluted solution is measured at $270 \mathrm{~nm}$ using a PDA detector.

Results: The assay method is linear from the concentration range of 5-30 $\mu \mathrm{g} / \mathrm{ml}$. The corelation coefficient is 0.9998 . The mean percentage recovery for the developed method is found to be in the range of 98.4-100.6\%. The developed method complies robustness studies.

Conclusion: The validation of the developed method was done by as per the ICH guidelines. It obeys the linearity, accuracy, precision, and robustness studies. Validation parameters are within the limitations. The results of the developed process indicated the reverse phase chromatographic method is simple, accurate as well as precise, rapid and eco-friendly method for routine analysis of ofloxacin in bulk and its pharmaceutical dosage form

Keywords: Reverse phase high performance liquid chromatography, Validation, Tablets, Ofloxacin.

(C) 2018 The Authors. Published by Innovare Academic Sciences Pvt Ltd. This is an open access article under the CC BY license (http://creativecommons. org/licenses/by/4. 0/) DOI: http://dx.doi.org/10.22159/ajpcr.2018.v11s4.31700

\section{INTRODUCTION}

Ofloxacin[1-3] isasyntheticbroad-spectrumantimicrobialagent.Ofloxacin is a fluorinated carboxyquinolone; it is the racemate substance. The IUPAC name of ofloxacin is $( \pm$ ) 9 fluoro-2, 3, dihydro- 3methyl -10 (4methyl-1piperazenyl)-7 oxo-7H pyrido[1, 2, 3-de]-1, 4-benzoxazine-6-carboxylic acid. Ofloxacin is a quinolone derivative, containing the one or more fluorine substitutions. The fluoroquinolones the first generation was introduced in 1980 have one fluoro substitution. The compounds with additional fluoro and other substitutions have been developed in 1990 - the developed compound extending the antimicrobial activity to Grampositive cocci and anaerobes.

The molecular formula is $\mathrm{C}_{18} \mathrm{H}_{20} \mathrm{FN}_{3} \mathrm{O}_{4}$ and molecular weight of the compound is $361.368 \mathrm{~g} / \mathrm{mol}$, and melting point of the compound is 250$257^{\circ} \mathrm{C}\left(482-495^{\circ} \mathrm{F}\right)$ (Fig. 1). It is more [3] potent against Gram-positive and anaerobes. It inhibits the growth of bacteria by inhibiting bacterial cell division. The growth of bacteriacell division inhibited by DNA gyrase enzyme, a type II topoisomerase IV enzyme. It is an enzyme necessary to separate and replicated DNA the literature survey showed that there are some analytical methods reported for ofloxacin such as spectrophotometric [4-6], liquid chromatographic [7-10], and high-performance thin-layer chromatography [11] individually or in combination with other drugs. The reported method is simple, sensitive, accurate, precise, and reliable for the determination of ofloxacin in bulk and formulation. The proposed method validated according to the ICH GuidelinesQ2 (R1) [12].

\section{EXPERIMENT}

\section{MATERIALS AND METHODS}

Materials

The ofloxacin pure standard drug was collected from Sai Mirra Pharmaceuticals Pvt. Ltd., Chennai. The tablet dosage form (ofloxacin $200 \mathrm{mg}$ ) was procured from local market analytical grade chemicals, and HPLC grade solvents are procured from Merck Specialties Pvt. Ltd. (Mumbai, India).

\section{Instrumentation}

A automatic Shimadzu reversed-phase high-performance liquid chromatographic system consists of a LC-20 AD solvent delivery system (pump), SPD-M20A photodiode array detector, rheodyne injector with $20^{\circ} 5 \mathrm{~L}$ loop volume, and LC- (class VP Software solution) assisted for data collections and processing. The analysis was carried out using Hypersil silica $\left(\mathrm{C}_{18} 250 \mathrm{~mm} \times 4.6 \mathrm{~mm}, 5 \mu\right)$. The process was carried out at ambient temperature. The HPLC grade methanol and water in the ratio of $10: 90$ and flow rate of mobile phase at $1.0 \mathrm{ml} / \mathrm{min}$. The detection wavelength is $270 \mathrm{~nm}$.

\section{Methodology}

Mobile phase

The mobile phase is prepared by mixing chromatographic grade methanol and water in the ratio of $(90: 10) \mathrm{v} / \mathrm{v}$. The mixed solvents are sonicated at $3000 \mathrm{rpm}$ and keep it as a mobile phase.

\section{Standard solution}

The $50 \mathrm{mg}$ of standard powder drug was weighed and transferred into $50 \mathrm{ml}$ standard flask. Dilute the drug with methanol to make the concentration of $1 \mathrm{~m}$. Further dilutions are made using methanol and prepare $10 \mu \mathrm{g} / \mathrm{ml}$ solutions.

\section{Sample solution}

Weigh accurately 20 tablets and the average weight was calculated. The amount of powdered tablet is equivalent to $50 \mathrm{mg}$ and transferred to $50 \mathrm{ml}$ volumetric flask, then add HPLC grade methanol and try to dissolve as it possible. The solution was filtered through Whatman filter paper. The filtrate was further diluted with the methanol to 
prepare the final concentration of working sample equivalent to $10 \mu \mathrm{g} / \mathrm{ml}$ solution.

\section{Working procedure}

The stabilization of chromatographic system is done by passing mobile phase continuously and developed baseline graph. The detector wavelength was set at $270 \mathrm{~nm}$ by UV spectra and flow rate fixed at $1.0 \mathrm{~mL} / \mathrm{min}$. First to inject the blank solution followed by six replicates of the single standard solution then collected the chromatogram. The system suitability parameters are verified. The six replicates of standard solutions $5,10,15,20,25$, and $30 \mu \mathrm{g} / \mathrm{mL}$ are injected. The calibration curve is plotted between the concentration and peak area. The linearity curve showed by Fig. 2. The amount of drug substance present in sample solution calculated by the direct comparison method.

\section{Method validation}

\section{System suitability}

The system suitability test for a developed chromatographic procedure is relative standard deviation (RSD) $<2 \%$, tailing factor $<1.5$, and theoretical plates $>1500$. The chromatographic parameters are evaluated for the developed process.

\section{Linearity}

The linearity was studied using five standard solutions covering the range of $5-30 \mu \mathrm{g} / \mathrm{ml}$ of ofloxacin. The $1.0 \mathrm{ml}, 1.5 \mathrm{ml}, 2.0 \mathrm{ml}, 2.5 \mathrm{ml}$, and $3.0 \mathrm{ml}$ of aliquots of stock solution are pipetted out into $50 \mathrm{ml}$ standard flasks and diluted to the mark with the mobile phase to get the concentrations of $5 \mu \mathrm{g} / \mathrm{ml}, 10 \mu \mathrm{g} / \mathrm{ml}, 15 \mu \mathrm{g} / \mathrm{ml}, 20 \mu \mathrm{g} / \mathrm{ml}$, and $25 \mu \mathrm{g} / \mathrm{ml}$ of ofloxacin.

\section{Detection limit (LOD) and quantification limit (LOQ)}

From the linearity studies, we determine the LOD and LOQ. The standard deviation, intercept, and slope value are used for calculation.

\section{Method precision}

The method precision was verified by interday and intraday analysis, the measurement of peak areas of repeated solutions $15 \mu \mathrm{g} / \mathrm{ml}$ of ofloxacin.

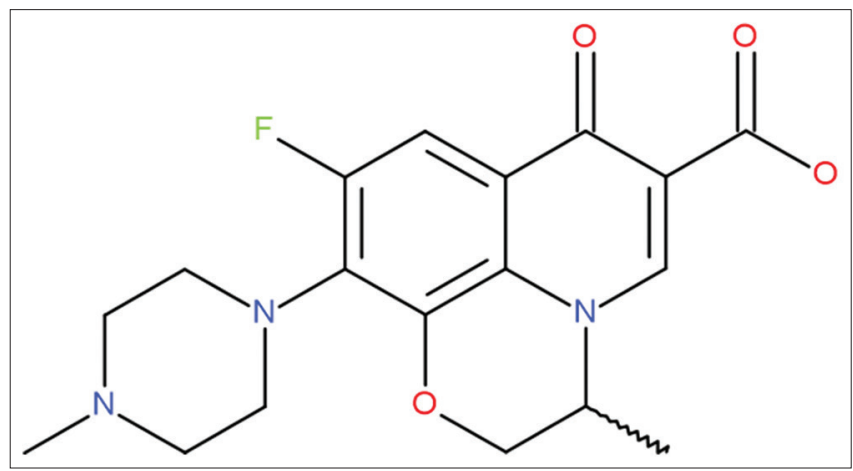

Fig. 1: Molecular structure of ofloxacin
Accuracy

The accuracy of the developed method calculated by recovery studies the $50 \%, 100 \%$, and $150 \%$ of the different working strength of ofloxacin was used for recovery study.

\section{Robustness}

Robustness is the one of the validation parameter. It verified by changing small, unique changes in method parameters such as flow rate and detection wavelength of the method parameter. We did the changes in detection wavelength $\pm 2 \mathrm{~nm}$ changes and flow rate was varied $\pm 0.2 \mathrm{ml} / \mathrm{min}$.

\section{RESULTS AND DISCUSSION}

A simple reversed-phase chromatographic process was reported for the estimation of ofloxacin in bulk and marketed formulation. The optimization process for chromatographic parameters carried out by changing the mobile phase composition.

\section{Mobile phase characteristics}

The ideal separation of the drug was done using isocratic condition. The HPLC grade water and methanol are supplied in the ratio of 10:90 $(\mathrm{v} / \mathrm{v})$ as the mobile phase. The sharp peak with baseline separation is developed by doing a number of experiments and then only we selected the mobile phase. The interfering peaks are peaks removed by doing number of experiments. It was proved that the selected solvent is more suitable for this analytic. The chromatographic peak was defined better, resolved, and almost free from tailing effect. Asymmetric peak

Table 1: Optimized chromatographic conditions of ofloxacin parameters

\begin{tabular}{ll}
\hline Parameters & Results \\
\hline Mobile phase & Methanol: water (90:10) \\
Column & $\mathrm{C}-18$ \\
Diluent & Methanol \\
Column temperature & $30^{\circ} \mathrm{C}$ \\
Wavelength & $270 \mathrm{~nm}$ \\
Volume of Injection & $20 \mu \mathrm{l}$ \\
Mobile phase flow rate & $1.0 \mathrm{ml} / \mathrm{min}$ \\
Runtime & $10 \mathrm{~min}$ \\
Retention time & $3.4 \mathrm{~min}$ \\
Theoretical plates & 4033 \\
Asymmetry factor & 1.46 \\
Capacity factor & 0.98 \\
\hline
\end{tabular}

Table 2: Linearity study of ofloxacin

\begin{tabular}{ll}
\hline Amount in sample solution $(\boldsymbol{\mu g} / \mathbf{m l})$ & Area \\
\hline 5 & 70,363 \\
10 & $1,40,764$ \\
15 & $2,11,107$ \\
20 & $2,81,430$ \\
25 & $3,51,761$ \\
30 & $4,22,174$ \\
\hline
\end{tabular}

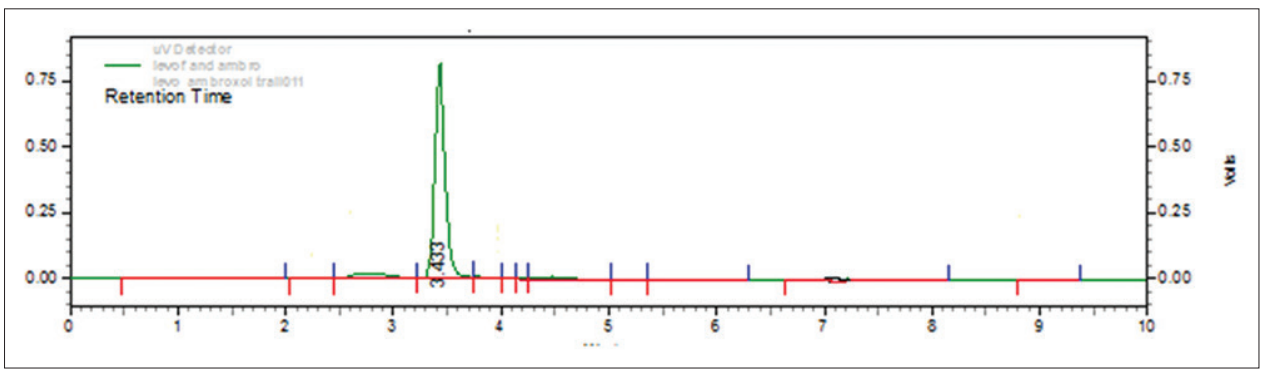

Fig. 2: Optimized chromatogram of ofloxacin sample 
of ofloxacin obtained using the selected mobile phase with shorter analysis time. The mobile phase containing only methanol and water, both are eco-friendly solvents, and it does not produce harmful effects to the environment. The Chromatographic condition Ofloxacin parameters showed in the Table 1 .

\section{Linearity}

The linearity study verifies that the concentration of selected drug ofloxacin obeys the Beer's and Lambert's law limit. Where analyte response is linearly proportional to concentration. The linearity studies carried out by taking in the concentration range of $5-30 \mu \mathrm{g} / \mathrm{mL}$. The result is indicated that the peak areas are linear within the concentration of analysis. The correlation coefficient was $\mathrm{R}^{2}=1$ (Fig. 3). The Linearity values of Ofloxacin showed in the Table 2

\section{Accuracy}

The standard addition method was used for accuracy studies. The pre-analyzed sample solution treated with standard solution. The percentage recovery was calculated using peak area. The satisfactory recoveries of $98 \%, 99.33 \%, 99.06 \%, 100.06 \%$, and $101.33 \%$ are

Table 3: Recovery studies of ofloxacin

\begin{tabular}{|c|c|c|c|c|c|c|c|c|}
\hline Drug & Sample no. & $\begin{array}{l}\text { Concentration } \\
\text { taken } \mu \mathrm{g} / \mathrm{ml}\end{array}$ & $\begin{array}{l}\text { Concentration } \\
\text { added } \mu \mathrm{g} / \mathrm{ml}\end{array}$ & $\begin{array}{l}\text { Amount } \\
\text { determined } \mu \mathrm{g} / \mathrm{ml}\end{array}$ & $\begin{array}{l}\text { Amount } \\
\text { recovered } \mu \mathrm{g} / \mathrm{ml}\end{array}$ & \% Recovered & S.D & \% RSD \\
\hline \multirow[t]{5}{*}{ Ofloxacin } & 1. & 15 & 15 & 30.01 & 14.70 & 98.00 & & \\
\hline & 2. & 15 & 15 & 30.12 & 14.90 & 99.33 & 1.23 & 2.00 \\
\hline & 3. & 15 & 15 & 28.56 & 14.86 & 99.06 & & \\
\hline & 4. & 15 & 15 & 29.92 & 15.01 & 100.06 & & \\
\hline & 5. & 15 & 15 & 29.95 & 15.20 & 101.33 & & \\
\hline
\end{tabular}

RSD: Relative standard deviation

Table 4: Intraday analysis of ofloxacin

\begin{tabular}{|c|c|c|c|c|c|c|c|}
\hline Drug & Sample no. & Amount taken* $(\mu \mathrm{g} / \mathrm{ml})$ & Amount found $(\mu \mathrm{g} / \mathrm{ml})$ & Percentage obtained & Average \% & S.D & \%RSD \\
\hline \multirow[t]{3}{*}{ Ofloxacin } & 1. & 15 & 14.88 & 99.2 & & & \\
\hline & 2. & 15 & 14.83 & 98.87 & 97.80 & 0.9582 & 1.82 \\
\hline & 3. & 15 & 15.10 & 100.67 & & & \\
\hline
\end{tabular}

Average value of six replicates, RSD: Relative standard deviation

Table 5: Interday analysis of ofloxacin

\begin{tabular}{|c|c|c|c|c|c|c|c|}
\hline Drug & Sample no. & Concentration taken $(\mu \mathrm{g} / \mathrm{ml})$ & Concentration found $(\mu \mathrm{g} / \mathrm{ml})$ & Percentage obtained & Average \% & S.D & \%RSD \\
\hline \multirow{3}{*}{ Ofloxacin } & 1. & 15 & 14.73 & 98.2 & \multirow{3}{*}{99.00} & \multirow{3}{*}{1.3781} & \multirow{3}{*}{2.00} \\
\hline & 2. & 15 & 14.86 & 99.07 & & & \\
\hline & 3. & 15 & 15.14 & 100.9 & & & \\
\hline
\end{tabular}

RSD: Relative standard deviation

Table 6: Quantification of the formulation

\begin{tabular}{|c|c|c|c|c|c|c|c|}
\hline Sample name & Sample no. & Added amount $(\mu \mathrm{g} / \mathrm{ml})$ & Amount present $(\mu \mathrm{g} / \mathrm{ml})$ & Percentage obtained & Mean value in \% & S.D & RSD in \% \\
\hline \multirow{5}{*}{ Ofloxacin } & 1. & 15 & 14.89 & 99.26 & \multirow{5}{*}{99.09} & \multirow{5}{*}{1.4189} & \multirow{5}{*}{1.00} \\
\hline & 2. & 15 & 14.99 & 99.87 & & & \\
\hline & 3. & 15 & 14.59 & 97.26 & & & \\
\hline & 4. & 15 & 15.14 & 100.9 & & & \\
\hline & 5. & 15 & 14.73 & 98.2 & & & \\
\hline
\end{tabular}

RSD: Relative standard deviation

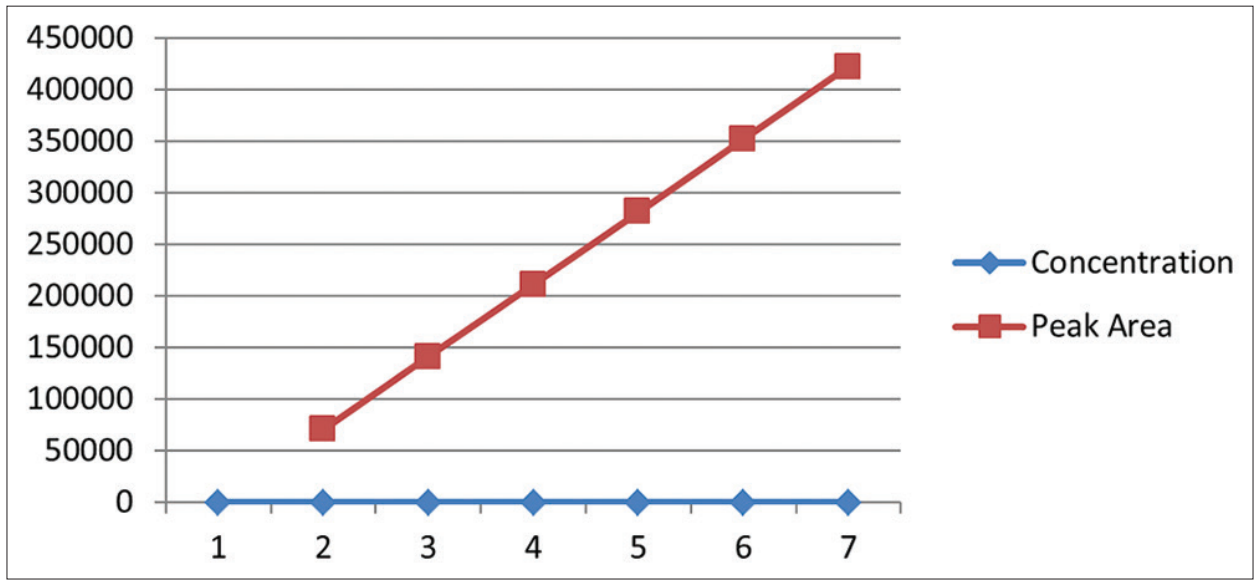

Fig. 3: Linearity curve of ofloxacin 
obtained for the developed method. It indicates that the method was complies the accuracy studies. The Recovery studies values of Ofloxacin showed in Table 3.

\section{Intraday precision}

The intraday precision analysis, we are used for three replicate standard solutions $(15 \mu \mathrm{g} / \mathrm{ml})$ of ofloxacin. The recovery of the drug analyzed as per the ICH guidelines. The percentage RSD was calculated, and it was found that 1.82. It indicates that the proposed method is more précised. The intraday analysis of Ofloxacin showed in the Table 4.

\section{Interday precision}

The interday precision analysis was done using six replicates of ofloxacin standard solutions $(15 \mu \mathrm{g} / \mathrm{ml})$. The percentage RSD was calculated, and it was found to be 1.2781 . It indicates the developed method complies reproducibility. The Interday analysis of Ofloxacin showed in the Table 5 .

\section{Specificity}

The additives present in the formulation are verified, and the specificity values for the developed method are within limit. Hence, the developed method chromatographic parameters are specific for ofloxacin, excipients, and others.

\section{LOD and LOQ}

The LOQ estimated by injecting the standard solutions. A signal-tonoise ratio $(\mathrm{S} / \mathrm{N})$ of 3 is a limit to accepted for estimating LOD and S/N ratio of 10 is used for estimating LOQ. This method is commonly used to exhibit baseline noise. The LOD and LOQ for ofloxacin were found to be $2.24 \mu \mathrm{g} / \mathrm{ml}$ and $62.4 \mu \mathrm{g} / \mathrm{ml}$, respectively.

\section{System suitability}

The system suitability test of the proposed method to evaluate the chromatographic parameters before the validation runs. The validation of the developed method was done as per the ICH validation guidelines.

From the linearity studies, we found that the drug obeys Beer's and Lambert's law within the sample concentration range. The percentage recovery of pure drug was $98-100.06 \%$, it indicates that the developed method was accurate and more precise. Specificity of the method indicated the excipients and degradation products present in the formulations but it not interfering the reported method. The precision studies indicated that the developed method has good reproducibility. The system suitability parameters also reveal that the values are within the specified limits for the developed method. The test procedure for ofloxacin tablet was validated and found that the developed method is complies the validation parameters. The Ofloxacin sample formulation assay values are showed in Table 6

\section{CONCLUSION}

An eco-friendly, rapid, and cost-effective liquid chromatographic method was developed for the analysis of ofloxacin in drug and pharmaceutical dosage form. The Hyper Persil Silica ( $250 \times 4.6 \mathrm{~mm}$, packed with $5 \mu \mathrm{m}$ ) column was used. The carrier solution contains methanol and water in the ratio of $90: 10$ and supplied to column by isocratic mode. The respective linear regression equation being $y=70353 x+29.6$ and the correlation coefficient was $R^{2}=1$. The mobile phase supplied at $1.0 \mathrm{ml} / \mathrm{min}$ and eluted substance is analyzed at $270 \mathrm{~nm}$. The retention time of ofloxacin was found to be $3.4 \mathrm{~min}$. The linearity of the developed method was $5-30 \mu \mathrm{g} / \mathrm{ml}$. The percentage recovery was found to be 98-101.03\%; it indicates that the developed method is accurate as well as the excipients present in the formulation not interfere the process. We are used only methanol and water as the mobile phase. The both solvents are environment safe so that developed method is eco-friendly. The percentage RSD value of precision analysis is $<2 \%$; it indicates that the developed method has complied reproducibility parameters. The system suitability parameters also reveal that the reported values are within the specified limits for the developed method. The developed reverse phase chromatographic method is an eco-friendly, sensitive, precise, and accurate method for the estimation of ofloxacin and marketed formulation.

\section{ACKNOWLEDGMENTS}

The authors are thankful to the Department of Pharmaceutical Chemistry and Analysis, School of Pharmaceutical Science, Vels Institute of Science Technology and Advanced Studies (VISTAS) Chennai, India, for providing technical support and facilities to carry out the research work. The authors also express their gratitude to Sai Mirra Pharmaceuticals Pvt. Ltd., Chennai, India, for providing a gift sample of pure drugs.

\section{AUTHORS' CONTRIBUTION}

Conceived and designed the topic and compile the collected data: Wrote the first draft of the manuscript: M. Sumithra. Contributed to the writing of the manuscript: Attah Samuel Attah, A. Gnana Sowndariya. Agree with manuscript results and conclusions and jointly developed the structure and arguments for the paper. Made critical revisions and approved final version: All authors reviewed and approved of the final manuscript.

\section{CONFLICTS OF INTEREST}

There are no conflicts of interest.

\section{REFERENCES}

1. The Internet Drug Index. Specialized Information Services. Available from: http://www.rxlist.com/floxin-drug/indications-dosage.htm. [Last cited on 2018 Jan 02].

2. Parfitt K. Martindale the Complete Drug Reference. London: The Pharmaceutical Press; 1999. p. 233-89.

3. Maryadele JO. Merck Index. Whitehouse Station, NJ: Merck and Co.; 2001. p. 9525.

4. Daharwal SJ, Swarnlata S, Saraf S. Spectrophotometric methods for estimation of ofloxacin and tinidazole from tablet dosage form. Indian Pharm 2008;7:73-9.

5. Kumar R, Singh P, Singh H. Development of colorimetric method for the analysis of pharmaceutical formulation containing both ofloxacin and cefixime. Int J Pharm Pharm Sci 2011;3:178-9.

6. Suslu N, Tamer A. Application of bromophenol blue and bromocresol purple for the extractive-spectrophotometric determination of ofloxacin. Anal Lett 2003;36:11163-81.

7. Gandhimathi M, Ravi TK, Nilima S. Validated high performance thin layer chromatography method for simultaneous estimation of ofloxacin and ornidazole in tablet dosage form. Indian J Pharm Sci 2006;68:838-40

8. Ohkubo T, Kudo M, Sugawara K. Determination of ofloxacin in human serum by high-performance liquid chromatography with column switching. J Chromatogr B: Biomed Sci Appl 1992;573:289-93.

9. Kamble NS, Venkaachalm A. High performance liquid chromatography determination of ornidazole and ofloxacin in solid dosage form. Indian Drugs 2005;42:723-5.

10. Khandagle KS, Gandhi SV, Deshpande PB, Gaikwad NV. A simple and sensitive RP-HPLC method for simultaneous estimation of cefixime and ofloxacin in combined tablet dosage form. Int J Pharm Sci 2011;3:46-8.

11. Sumithra M. Application of quality by design (CCD Technique) for simultaneous estimation of cefixime and ofloxacin by HPTLC method. Int J Pharm Pharm Sci 2016;8:200-8.

12. Validation of Analytical Procedure: Methodology Q2B, ICH Harmonized Triplicate Guidelines; 1996. p. 1-8. 